ALCHEMY Jurnal Penelitian Kimia

Laman resmi: https://jurnal.uns.ac.id/alchemy

\title{
Kajian Metal-Organic Frameworks (MOFS) sebagai Material Baru Pengantar Obat
}

\author{
Qonita Awliya Hanif $^{a}$, Reva Edra Nugrahab ${ }^{b}$ dan Witri Wahyu Lestari ${ }^{a, c^{*}}$ \\ ${ }^{a}$ Program Studi Ilmu Kimia, Program Pascasarjana, Universitas Sebelas Maret, Jl. Ir. Sutami 36 A, \\ Kentingan-Jebres Surakarta, Jawa Tengah, Indonesia, 57126, Tel, Fax: +62 271663375 \\ ${ }^{b}$ Program Studi Kimia, Program Magister, Institut Teknologi Sepuluh November, Jl. Raya ITS, Keputih, \\ Sukolilo, Surabaya, Jawa Timur, Indonesia, 60111, (031) 5994251 \\ 'Program Studi Kimia, Fakultas Matematika dan Ilmu Pengetahuan Alam, Universitas Sebelas Maret, Jl. Ir \\ Sutami No.36A, Kentingan-Jebres Surakarta, Jawa Tengah, Indonesia, 57126. Fax: +62 271 663375; Tel: \\ +62 271663375, Hp: +6282227833424 \\ * Corresponding author \\ E-mail: witri@mipa.uns.ac.id \\ DOI: 10.20961/alchemy.14.1.8218.16-36
}

Received 14 March 2017, Accepted 11 December 2017, Published 1 March 2018

\begin{abstract}
ABSTRAK
Metal-Organic Frameworks (MOFs) merupakan material berpori baru yang berpotensi sebagai pengantar dan pelepas lambat obat. Strukturnya yang fleksibel, ukuran pori kristalin yang teratur, dan sisi koordinasi yang beragam merupakan beberapa kelebihan dari MOFs yang mendukung dalam enkapsulasi berbagai obat. Metode yang dapat digunakan untuk sintesis MOFs diantaranya nanopresipitasi, solvothermal, reverse microemulsion, dan reaksi solvothermal dengan template surfaktan. Karakterisasi material hasil sintesis maupun profil setelah enkapsulasi (loading) dapat dilakukan menggunakan Scanning Electron Micrscope (SEM), Transmission Electron Microscope (TEM), Differential Scanning Calorymetry (DSC), Fourier Transform Infra Red Spectroscopy (FTIR), dan Powder X-Ray Diffraction (PXRD). Metode loading obat terdiri dari dua kategori, yakni penggabungan agen biomedis secara langsung dan loading secara post synthesis. Sebelum MOFs diaplikasikan, perlu dilakukan aktivasi dan penempelan material obat. Pengujian lepas lambat dapat dijalankan pada beberapa kondisi seperti dalam Simulated Body Fluid (SBF), Phosphate Buffer Saline (PBS), Bovine Serum Albumin (BSA) maupun simulasi menggunakan Grand Canonical Monte Carlo (GCMC). Pengujian secara in vivo dan in vitro juga dapat dilakukan untuk mengetahui dampaknya pada tubuh makhluk hidup dan aktivitasnya terhadap sel patogen. Kombinasi organik linker dan ion logam pusat yang berbeda akan menghasilkan ukuran pori, fleksibilitas, kapasitas loading, profil pelepasan obat, toksisitas, dan kemampuan menginhibisi yang berbeda pula. Pada review kali ini akan dibahas tentang kajian singkat terkait struktur dan desain MOFs, bio-MOFs, nano bio MOFs, strategi sintesis, dan strategi loading dan pelepasan obat untuk aplikasi dalam biomedis. Selanjutnya akan diberikan beberapa contoh aplikasi yang sudah dilakukan sejauh ini misalnya beberapa jenis MOFs yang sudah dienkapsulasi dengan beberapa material obat, seperti 5-fluoracil, ibuprofen, doxorubicin, dan dikaji waktu pelepasannya dan interaksinya dengan permodelan komputasi.
\end{abstract}

Kata kunci: biomedis, enkapsulasi, MOFs, obat, pelepas lambat

\section{ABSTRACT}

Study of Metal-Organic Frameworks (MOFs) as a Novel Material for Drug Delivery. MetalOrganic Frameworks (MOFs) are a novel class of porous material that has wide potential applications 
including in drug delivery and slow release. Its flexible structure, regular crystalline pore size, and various coordination sites are some of the advantages of supporting MOFs properties in the encapsulation of various drugs. Various methods can be used for the MOFs synthesis include nanoprecipitation, solvothermal, reverse micro emulsion, and surfactant-templated solvothermal. Both characterization for synthesized materials and profile after encapsulation can be done using Scanning Electron Microscope (SEM), Transmission Electron Microscope (TEM), Differential Scanning Calorimetry (DSC), Fourier Transform Infra-Red Spectroscopy (FTIR), and Powder X-Ray Diffraction (PXRD). The drug loading method consists of two categories, namely the direct incorporation of biomedical agents and post-synthesis method. Before MOFs are applied in biomedical application, activation and attachment of medicinal materials should be performed. Meanwhile, for slow release testing can be run on several conditions such as in Simulated Body Fluid (SBF), Phosphate Buffer Saline (PBS), Bovine Serum Albumin (BSA) and simulation using Grand Canonical Monte Carlo (GCMC). In vivo and in vitro testing can also be done to determine the impact on the body of living creatures and their activity on pathogen cells. Different organic linker and metal center combinations will result in pore size, flexibility, loading capacity, drug release profiles, toxicity, and different inhibiting ability. Herein, we will discuss a brief review of the structure and design of MOFs, bio-MOFs, nano-bio MOFs, synthesis, drug loading and release strategies for applications in biomedicine. Furthermore, there will be some examples of applications that have been done so far, e.g. some types of MOFs that have been encapsulated with some medicinal materials, such as 5-fluorouracil, ibuprofen, doxorubicin, and reviewed its release time and interaction with computational modeling.

Keywords: biomedical, drugs, encapsulation, MOFs, slow-release

\section{PENDAHULUAN}

Metal-Organic Frameworks (MOFs) yang disebut juga polimer koordinasi berpori merupakan material hibrid organik-anorganik berpori yang terbentuk secara self-assembly. Material ini terdiri dari ion logam atau klaster oksida logam dengan suatu ligan bivalen atau polivalen aromatik maupun alifatik yang memiliki gugus fungsional karboksilat, fosfonat, sulfonat, imidazolat, amina, atau pyridil maupun kombinasinya sebagai senyawa organik penghubung (linker). Sebagaimana yang diilustrasikan pada Gambar 1, ion logam (klaster oksida logam) sebagai node (simpul) berkoordinasi dengan linker organik dan akan membentuk suatu rangka (framework) yang disebut MOFs. Ion logam yang pernah dikaji diantaranya golongan alkali tanah seperti kalsium $\left(\mathrm{Ca}^{2+}\right)$, magnesium $\left(\mathrm{Mg}^{2+}\right)$ (Yang et al., 2012), alumunium $\left(\mathrm{Al}^{3+}\right)$ (Joaristi et al., 2012), logam transisi seperti besi $\left(\mathrm{Fe}^{3+}\right)$ (Horcajada et al., 2006), kromium $\left(\mathrm{Cr}^{6+}\right)$ (Horcajada et al., 2008), seng $\left(\mathrm{Zn}^{2+}\right)$ (Li et al., 1999), tembaga $\left(\mathrm{Cu}^{2+}\right)$ (Seo et al., 2009), kobalt $\left(\mathrm{Co}^{2+}\right)$ (Cho et al., 2012), zirkonium $\left(\mathrm{Zr}^{4+}\right)$ (Abid et al., 2012) maupun lanthanida seperti gadolinium $\left(\mathrm{Gd}^{3+}\right)$ (Kathryn et al., 2008). Sedangkan linker organik yang pernah diteliti yakni asam mukonat, asam fumarat, asam trimesat, asam tereftalat, dan asam amino tereftalat (Horcajada et al., 2010). MOFs memiliki karakteristik yang menarik, diantaranya kemampuan struktur untuk dapat beradaptasi, sifat fleksibilitasnya, pori kristalin yang teratur, dan sisi koordinasi yang beragam (Sun et al., 2017). Begitu banyak jumlah MOFs yang dapat disintesis dengan kombinasi organik linker dan logam pusat menjadi peluang untuk mengatur luas permukaan, ukuran pori, dan gugus fungsional pada permukaannya (Tranchemontagne et 
al., 2009). Sifat fisika dan kimia MOFs yang menarik tersebut membuatnya dapat diaplikasikan pada penyimpanan dan pengantaran obat (Taylor et al., 2010), katalis (Lee et al., 2009), sensor, material luminescent (Allendorf et al., 2009), penyimpanan gas (Rosi et al., 2003), dan pemisahan gas (Li et al., 2009).

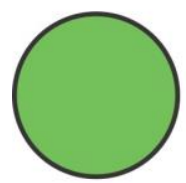

ion logam

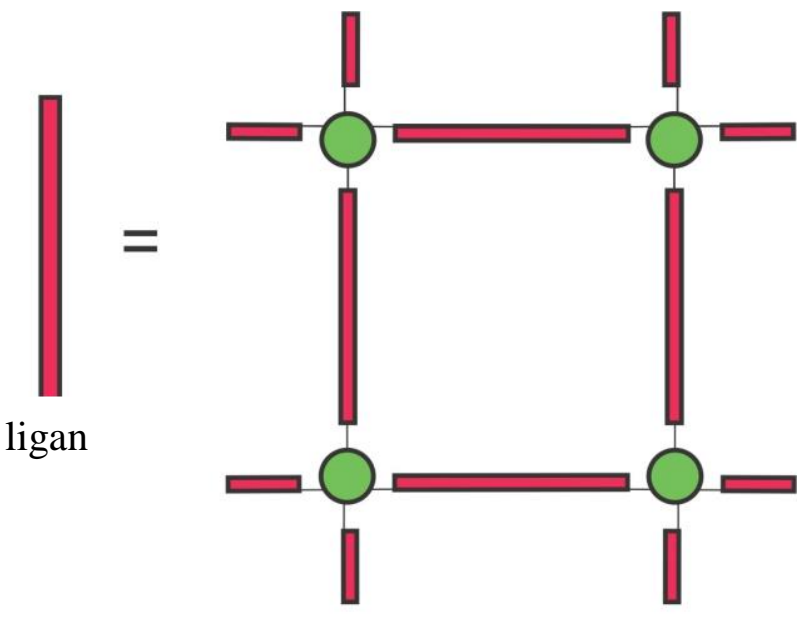

metal organic framework

Gambar 1. Proses terbentuknya Metal Organic Frameworks secara umum

MOFs memiliki beberapa kelebihan jika dibandingkan dengan sistem pembawa obat sebelumnya seperti liposom (Bangham and Horne, 1964) maupun polimer (Riehemann et al., 2009). Kelebihan tersebut diantaranya struktur yang dapat diatur sesuai kebutuhan, dengan merubah ion logam dan atau organik linkernya sehingga memiliki ukuran pori tertentu. Ukuran pori umumnya disesuaikan dengan ukuran obat yang akan diloading. Selain itu, luasnya permukaan MOFs juga memberikan potensi dalam loading obat. Semakin besar luas permukaan, ukuran maupun jumlah pori, enkapsulasi obat dengan kapasitas yang lebih banyak akan lebih memungkinkan (Sun et al., 2013).
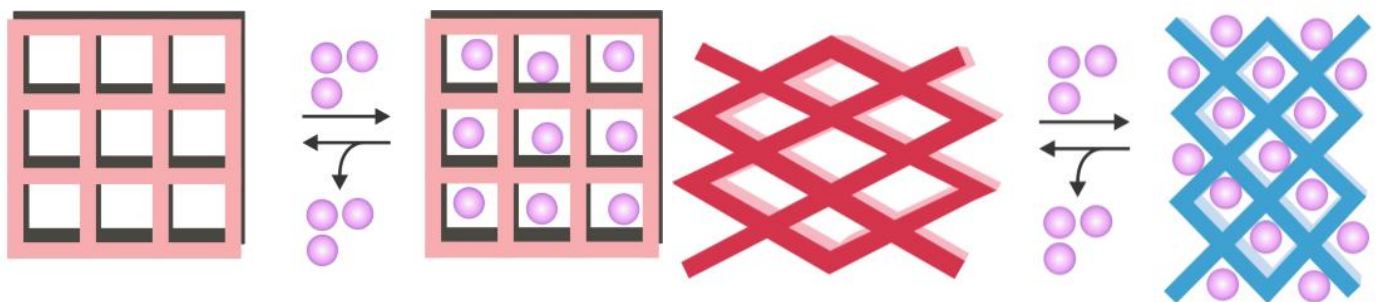

Gambar 2. Ilustrasi enkapsulasi dan pelepasan obat oleh MOFs

Kelebihan lain yaitu kerangka MOFs yang didesain dapat menghasilkan sifat fleksibel pada MOFs sehingga mampu beradaptasi pada porinya untuk menyesuaikan bentuk maupun ukuran molekul organik (Horcajada et al., 2006). Sifat-sifat inilah yang menjadikan MOFs dapat digunakan baik sebagai loading obat maupun mengontrol pelepasan obat pada area target dalam tubuh (Sindoro et al., 2014). Secara umum, tahapan penyimpanan dan pelepasan obat diilustrasikan pada Gambar 2. Obat tertentu yang di- 
loading dengan MOFs akan menghasilkan obat terenkapsulasi MOFs. Pada proses loading obat dapat masuk pada pori-pori MOFs ataupun berada dipermukaan dan berinteraksi secara fisika selama beberapa waktu. Interaksi yang tidak terlalu kuat ini memungkinkan obat dapat tersimpan dan akan terlepas secara mudah pada periode tertentu tergantung pada jumlah maupun kekuatan interaksinya. Sehingga obat dapat terlepas dari MOFs dan bereaksi dengan sel yang sakit.

\section{DESAIN MOFS, SINTESIS, DAN STRATEGI LOADING}

Metode yang dapat digunakan untuk sintesis MOFs diantaranya; nanopresipitasi, solvothermal, reverse microemulsion, dan reaksi solvothermal dengan template surfaktan. Metode nanopresipitasi cenderung menghasilkan material produk yang amorf. Adapun ketiga metode lainnya memberikan produk yang kristalin. Dua metode pertama tidak menggunakan surfaktan, sedang dua metode berikutnya perlu ditambahkan surfaktan untuk mengontrol sintesis dan menstabilkan partikel. Sintesis MOFs dengan solvothermal dapat dicapai dengan pemanasan konvensional atau menggunakan microwave. Pada metode solvethermal, temperatur reaksi yang tinggi menyebabkan transformasi prekursor terjadi sebelum terbentuknya MOFs. Kecepatan pemanasan dan temperatur merupakan parameter tambahan untuk mengatur nukleasi dan pembentukan partikel MOFs (Rocca et al., 2011).

\section{Strategi loading}

Secara umum, metode dalam pengapsulan (loading) obat terdiri dari dua kategori, yakni penggabungan agen biomedis secara langsung (saat awal sintesis MOFs) dan pengapsulan melalui metode post-synthesis (saat MOFs sudah terbentuk). Dua teknik ini diperlihatkan pada Gambar 3. Teknik penggabungan secara langsung (a) umumnya menggunakan material baik ligan maupun ion logamnya memiliki sifat yang membuatnya dapat diaplikasikan secara langsung tanpa perlu ditambahkan obat atau agen biomedis lainnya. Ion logam paramagnetik seperti $\mathrm{Gd}^{3+}, \mathrm{Fe}^{3+}$, dan $\mathrm{Mn}^{2+}$ yang tidak hanya berfungsi sebagai logam penghubung tetapi juga berperan sebagai agen peningkat kontras warna pada aplikasi Magnetic Resonance Imaging (MRI). Logam $\mathrm{Gd}^{3+}$ yang digabungkan dengan benzena dikarboksilat (BDC) maupun BDC terfungsionalisasi dengan gugus amin $\left(-\mathrm{NH}_{2}\right)$ dapat diaplikasikan sebagai pengontras MRI (Rieter et al., 2006). Ion logam $\mathrm{Mn}^{2+}$ dapat berfungsi sebagai pengontras MRI dan pengontras optik bila digabungkan dengan ligan BDC maupun benzena trikarboksilat (BTC) (Taylor et al., 2008). Adapun ion logam $\mathrm{Fe}^{3+}$ dapat berfungsi sebagai pengontras MRI dan pengontras optik bila digabungkan dengan dikarboksilat alkena rantai pendek sebagai ligannya (Horcajada et al., 2010). Pada 
aplikasinya sebagai pengantar obat, sintesis MOFs dengan metode penggabungan agen biomedis secara langsung juga telah dilakukan (Rieter et al., 2008). MOFs ini menggunakan ion logam $\mathrm{Tb}^{3+}$ dengan $c, c, t-\mathrm{Pt}\left(\mathrm{NH}_{3}\right)_{2} \mathrm{Cl}_{2}$ (succinate) $)_{2}$ atau cisplatin sebagai ligan sekaligus agen-agen anti kankernya.

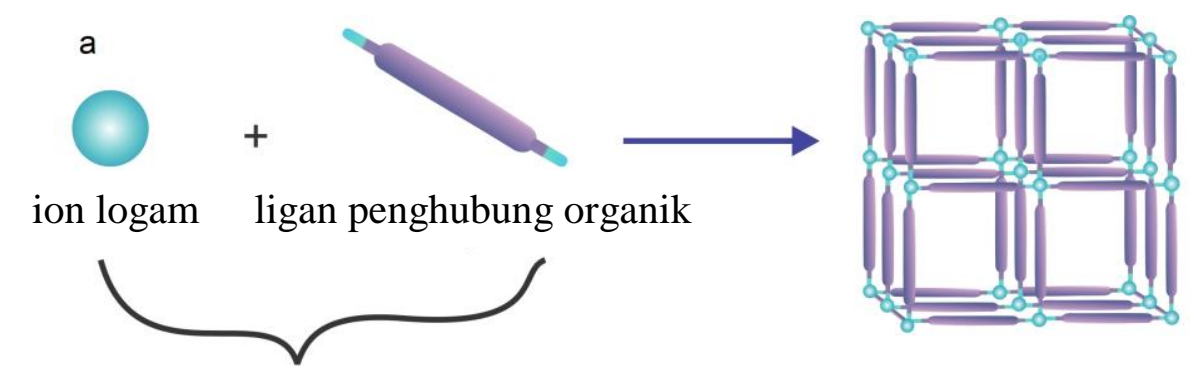

unit pembangun (building blocks)

MOFs untuk terapi dan imaging relevan secara biomedik

b1

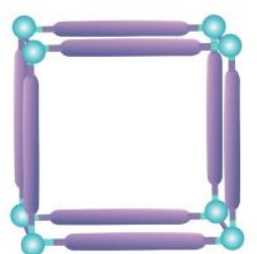

b2

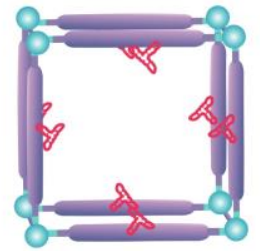

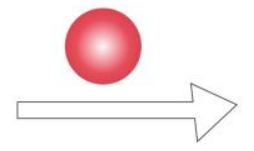

enkapsulasi secara non-kovalen

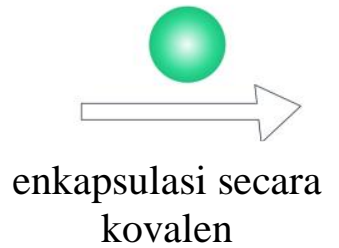

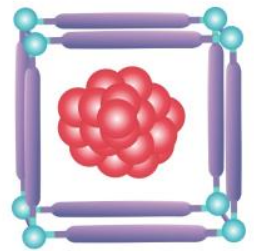

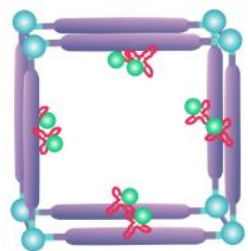

Gambar 3. Ilustrasi penggabungan agen biomedis secara langsung, penggabungan agen biomedis pada pori secara ikatan non kovalen, dan ikatan kovalen

Teknik penggabungan secara post-synthesis dapat dilakukan dengan loading agen aktif biomedisnya pada pori framework secara ikatan non kovalen (b1) maupun kovalen (b2). Adanya ikatan tersebut, MOFs melepas obat secara sangat lambat dan terus menerus, sehingga meminimalkan efek pelepasan obat secara besar-besaran. Masing-masing MOFs mempunyai kapasitas yang berbeda dalam menyimpan molekul obat. Kapasitas loading MOFs dapat mencapai 1,4 g untuk menyimpan obat ibuprofen. Telah dilakukan pula pengembangan loading obat lainnya yang bersifat hidrofilik, amfifilik, dan hidrofobik (Horcajada et al., 2010). Pada intinya, untuk mendapatkan kapasitas loading yang tinggi diperlukan ukuran pori dan luas permukaan yang optimum. 
Loading obat secara non kovalen merupakan proses yang reversibel, sehingga beberapa perlakuan akan memungkinkan terjadinya pelepasan obat secara dini. Penggabungan dengan ikatan kovalen lebih dapat menjaga obat dan hanya akan terlepas jika MOFs telah terdekomposisi. Pada metode ini, gugus fungsi yang berada pada pori framework akan mengikat agen aktif secara kovalen (Taylor et al., 2009). Seperti yang dilakukan oleh Horcajada et al. (2010), penggabungan $\mathrm{Fe}^{3+}$ dan ligan BDC yang difungsionalisasi dengan gugus amin $\left(-\mathrm{NH}_{2}\right)$ dapat diaplikasikan sebagai pengantar obat untuk azidotimidine (AZT) maupun cidofovir (CDV).

\section{DESAIN BIO-COMPATIBLE MOFS}

\section{Sejarah}

\section{a. Inisiasi Sintesis MOFs}

Pembuatan MOFs sebagai pengantar obat diinisiasi oleh Horcajada et al. dengan MIL-nya (Material Institut Lavoisier). MOFs yang kaku yakni MIL-100 dan MIL-101 memiliki kapasitas penyimpanan ibuprofen yang sangat tinggi mencapai 1,4 g/g material berpori. Pelepasan secara keseluruhan pada kondisi buffer membutuhkan waktu tiga hingga enam hari. Keduanya disintesis dari ion logam Fe(III) dengan senyawa tereftalat, asam tereftalat untuk MIL-101 dan asam trimesat untuk MIL-100 (Horcajada et al., 2006).

MIL-53 disintesis dengan ligannya asam tereftalat dan $\mathrm{Fe}^{3+/} \mathrm{Cr}^{3+}$ sebagai logamnya. MIL-53(Cr) dan MIL-53(Fe) dapat mengadsorpsi ibuprofen sebesar 0,22 g dan 0,21 g tiap gram materialnya secara berturut-turut. Kapasitas loading yang mencapai $20 \%$ berat ibuprofen untuk kedua material ini menunjukkan bahwa kemampuan adsorpsi tidak dipengaruhi oleh logam. Pelepasan ibuprofen secara keseluruhan membutuhkan waktu hingga tiga minggu (Horcajada et al., 2008). Sifat hampir sama yang ditunjukkan oleh kedua material ini memungkinkan penggunaan dari salah satu material saja yakni Fe $\left(\mathrm{LD}_{50}(\mathrm{Fe})=30 \mathrm{~g} \mathrm{~kg}^{-1} ; \mathrm{LD}_{50}(\right.$ asam tereftalat $\left.)>6,4 \mathrm{~g} \mathrm{~kg}^{-1}\right)$ dengan pertimbangan sifat toksik dari Cr (Goyer, 1996), sehingga toksisitas material berpori dapat diminimalisir dengan pemilihan logam tersebut.

Horcajada et al. (2010) juga mensintesis MIL-89 dengan ligan asam mukonat dan MIL-88A dengan asam fumarat sebagai ligannya. Kedua MIL ini dengan material MOFs berbasis Fe lainnya seperti MIL-100, MIL-101_NH2, dan MIL-53 diuji kemampuan loading-nya untuk beberapa obat antikanker ataupun antivirus seperti busulfan, azidotimidin trifosfat, cidofovir, dan doxorubicin. Kapasitas loading MIL-89 dan MIL-88A untuk busulfan berturut-turut 4,2\% dan 3,3\%. Sedangkan kapasitas loading obat cidovoir 
berturut-turut $81 \%$ dan $12 \%$. Baik MIL-89 maupun MIL-88A memiliki sifat fleksibel sehingga mampu menyesuaikan dengan ukuran obatnya (busulfan: 13,4 x 3,5, cidovoir: $10,8 \times 7,7)$.

Contoh material-material di atas masih disintesis dalam skala laboratorium. MOFs yang telah diproduksi hingga skala ton dan tersedia secara komersial diantaranya $\mathrm{Cu}$ trimesat atau HKUST-1 (Hong Kong University of Science and Technology) dengan nama trivial Basolit C300. MOFs lainnya yang juga telah disintesis dalam skala industri diantaranya alumunium-tereftalat atau MIL-53(Al) (Basolit A100), magnesium-formate (Basosiv M050), zink-2-metilimidazol (Basolite Z1200), dan besi-trimesat (Basolit F300) (Mueller et al., 2006).

\section{b. Bioaktif MOFs}

Senyawa MOFs yang telah ter-loading obat akan dapat melepaskan obat tersebut dengan disertai degradasi dari material MOFs itu sendiri pada kondisi fisiologis tubuh. Degradasi yang terjadi ini menimbulkan sifat toksik tambahan, sehingga untuk mengatasinya dibuatlah suatu material yang sekaligus berperan sebagai agen aktifnya. Material ini dapat disebut juga bioaktif MOFs. Telah dilaporkan sintesis dan pengujian bioaktif MOFs dengan ion logam berbasis Fe(III) dan asam nikotinat (piridin-3-asam karboksilat atau niacin atau vitamin B3) sebagai linkernya yang kemudian diberi nama Bio-MIL-1. Hasil kajian kinetika pelepasannya terjadi relatif cepat yakni satu jam pada kondisi Simulated Body Fluid (SBF) dengan suhu $37{ }^{\circ} \mathrm{C}$. Degradasi yang cepat ini dikarenakan rendahnya kestabilan material (Miller et al., 2010).

Agen aktif yang digunakan dapat berasal dari linker atau ion logamnya, seperti ion logam perak $\left(\mathrm{Ag}^{+}\right)$yang memiliki sifat antibakteri. Beberapa material nonpori berbasis polimer koordinasi menggunakan $\mathrm{Ag}^{+}$telah disintesis (Fromm, 2008) dan memperlihatkan sifat antimikroba. Telah dilaporkan pula sintesis MOFs berbasis Zn(II) dengan ligan endogenus seperti turunan fenil alanin dan tirosin serta ligan eksogenus politopik yang memiliki aktivitas terapis oleh Xie et al. (2007).

\section{c. Nano BioMOFs}

Selain sintesis bioMOFs yang lebih biokompatibel, telah dikembangkan pula material bioMOFs berskala nanometer yang dapat difungsikan sebagai pengantar untuk agen penginderaan maupun molekul obat yang disebut Nanoscale Metal-Organic Frameworks (NMOF) (Ma et al., 2010). Sistem nano memiliki beberapa kelebihan, yakni dapat meningkat aktivitas terapisnya, memperpanjang waktu hidup dari obat, menambah kelarutan obat yang hidrofobik, mengurangi potensi imunogenesitas, serta dapat melepas 
obat secara kontinyu maupun secara cepat. Kelebihan sistem nano tersebut dapat meminimalisasi efek toksik obat. Selain itu, partikel skala nano dapat terkumpul secara pasif pada jaringan yang spesifik (seperti tumor) melalui efek permeabilitasnya. Berdasarkan efisiensi nanosistem secara klinis tersebut, nanoteknologi dapat digunakan untuk mengembangkan terapi yang baru maupun untuk menghasilkan nanosistem generasi berikutnya sebagai pengantar obat yang pintar (Shi et al., 2010). MOFs dalam skala nano ini dapat diproduksi dengan inovasi metode sintesis misalnya melalui microwave assisted synthesis (Liu et al., 2017) maupun sonokimia (Qiu et al., 2008; Lestari et al., 2018).

\section{Aktivasi}

Sebelum MOFs diaplikasikan, perlu dilakukan aktivasi untuk menghilangkan molekul air ataupun pelarut lain yang terikat sebagaimana guest pada porinya. Aktivasi secara konvensional dilakukan dengan pemanasan material MOFs pada kondisi vakum. Perlakuan ini dapat menghilangkan ikatan koordinasinya dengan pelarut seperti air secara menyeluruh (Vimont et al., 2006). Namun di sisi lain, teknik sederhana ini menjadi pemicu hilangnya sebagian dan bahkan keseluruhan pori dari MOFs. Metode alternatif lain dilakukan oleh Eddaoudi et al. (2002), dimana MOFs diaktivasi dengan cara mengganti pelarut sisa pada MOFs dengan pelarut lain yang memiliki titik didih yang lebih rendah, baru kemudian pelarut tersebut dihilangkan. Sehingga dengan cara ini, porositas dari MOFs dapat dipertahankan. Namun pada beberapa kasus, metode penggantian pelarut ini tidak dapat menghasilkan luas permukaan pori seperti yang diharapkan. Cara lainnya dapat dilakukan melalui penggantian pelarut sisa selama sintesis MOFs dengan benzena kemudian penghilangan molekul benzena dengan pengondisian suhu yang rendah (freezedrying) (Ma et al., 2009).

Pada aplikasi MOFs sebagai pengantar obat, molekul obat tertentu dienkapsulasi melalui proses impregnasi. Ke et al. (2011), mensintesis material pengantar obat berupa komposit nanorod $\mathrm{Fe}_{3} \mathrm{O}_{4}$ dengan $\left[\mathrm{Cu}_{3}(\mathrm{BTC})_{2}\right]$ atau HKUST-1 untuk mengenkapsulasi obat nimesulide (NIM). NIM digabungkan dengan material komposit MOFs melalui pengadukan secara kontinyu selama 24 jam. Kapasitas loading obat dari material komposit berbasis MOFs ini mencapai 0,2 gram NIM per gram komposit dan terlepas secara keseluruhan setelah sebelas hari pada kondisi buffer. Nilai ini masih tergolong rendah jika dibandingkan penelitian terdahulu oleh Horcajada et al. (2006) yang berhasil mengenkapsulasi ibuprofen menggunakan MIL-100 dan MIL-101 melalui proses impregnasi, dimana kapasitas penyimpanannya mencapai 1,4 gram obat per gram material berpori. Jumlah ini juga lebih tinggi empat kali dibandingkan dengan material silika 
(MCM-41) (He and Shi, 2011) dan sembilan kali lebih banyak daripada kapasitas penyimpanan maksimum dengan zeolit (Horcajada et al., 2006). Modifikasi lain yang telah dilakukan berbasis MOFs HKUST-1 yakni pengompositan dengan $\mathrm{Fe}_{3} \mathrm{O}_{4}$ dan graphene oksida (GO). Tiga material gabungan ini menunjukkan peningkatan kapasitas loading secara sangat signifikan. Profil pelepasannya pun juga lebih lambat jika dibandingkan $\mathrm{Fe}_{3} \mathrm{O}_{4}$ saja maupun komposit HKUST-1/ $\mathrm{Fe}_{3} \mathrm{O}_{4}$. Dua fenomena ini terjadi karena adanya ikatan hidrogen yang terbentuk setelah penambahan GO yang menambah interaksi material pengantar dengan obat, sehingga penyimpanannya lebih banyak dan pelepasannya lebih lama (Li et al., 2017). Banyaknya konsentrasi GO dan banyaknya lapisan yang ditambahkan, mempengaruhi kapasitas loading dan pelepasan ibuprofen, dan diperoleh kondisi paling baik pada penambahan GO 10\% dengan lapisan GO sebanyak 20 (Li et al., 2016).

\section{Metode pengujian drug release}

\section{a. Simulasi pelepasan obat}

Material MOFs yang ter-loading obat umumnya disimulasikan pada kondisi tertentu. Kondisi ini disesuaikan dengan lingkungan biologis di dalam tubuh, seperti keasaman lambung, kebasaan dalam usus dan enzim. Maka pengujian dilakukan pada kondisi Simulated Body Fluid (SBF) yang merupakan sistem yang menyerupai sifat biologis tubuh dengan suhu $37{ }^{\circ} \mathrm{C}$ (Miller et al., 2010). Simulasi dapat pula dilakukan pada Phosphate Buffer Saline (PBS) maupun Bovine Serum Albumin (BSA) (Horcajada et al., 2010). Pada kondisi-kondisi tersebut, formulasi material pengantar yang diasosiasikan dengan obat dalam bentuk serbuk, pellet, tablet ataupun gel tidak secara cepat terlarut/ terdegradasi akan tetapi melalui proses yang berlangsung secara terus-menerus dari beberapa jam, hari, minggu atau lebih lama dari itu. Rentang ini dipengaruhi oleh beberapa faktor seperti struktur, komposisi, ukuran partikel, dan formulasinya (Hinks et al., 2010). Kuantitas obat yang terlepas dianalisa secara periodik menggunakan uv-vis spektrofotometer pada panjang gelombang tertentu, tergantung pada obat yang digunakan. Obat doxorubicin teridentifikasi pada panjang gelombang $460 \mathrm{~nm}$ sedang ibuprofen pada $264 \mathrm{~nm}$ (Sun et al., 2017). Metode lainnya seperti yang telah diteliti oleh Bernini et al. (2014) yakni menggunakan simulasi Grand Canonical Monte Carlo (GCMC). Model simulasi ini telah divalidasi dengan data eksperimen adsorpsi ibuprofen dan pelepasannya pada MIL-53, MIL-100, dan MIL-101. GCMC mampu memprediksi performa makroskopis dari material berpori, dan informasi yang detail mengenai struktur dan termodinamika selama proses berlangsung. 


\section{b. In Vivo}

Pengaplikasian MOFs pada bidang medis dibutuhkan pemahaman mengenai bagaimana proses pengantarannya, distribusinya, metabolisme/degradasinya, dan parameter yang berhubungan dengan toksisitas material. Maka kajian ini dilakukan dengan rute intravena pada tikus. Dosis yang digunakan hingga $220 \mathrm{mg} \mathrm{kg}^{-1}$ untuk nano-MOFs besi karboksilat yang berbeda struktur maupun ligannya, seperti endogenus-eksogenus, hidrofobik-hidrofilik, maupun linker alifatik-aromatik. Penyelidikan mengenai toksikologinya dilakukan selama tiga bulan setelah injeksi intravena, dengan memantau beberapa parameter seperti berat tubuh, tingkah laku hewan, organ, aktivitas enzim, dan serum biokimia (Horcajada et al., 2010). Adapun kajian biodistribusi material dilakukan dengan mengkuantifikasi jumlah logam maupun linker pada berbagai jaringan menggunakan Atomic Absorption Spectroscopy (AAS) untuk logamnya dan High Performance Liquid Chromatography (HPLC) untuk analisa kuantitatif dari linker senyawa organik.

\section{c. In Vitro}

Selain pengujian in vivo, material MOFs yang diaplikasikan pada bidang medis perlu dilakukan pengujian secara in vitro untuk mengetahui aktivitasnya dalam menghambat pertumbuhan virus maupun bakteri pada sel yang sakit. Cytotoksisitas MIL100 yang di-loading busulfan diuji dengan sel leukimia manusia (CCRF-CEM) dan human multiple myeloma (RPMI-8226) yang diperbandingkan dengan MIL-100 dan busulfan saja. Hasilnya MIL-100 dapat menghantarkan secara keseluruhan busulfan yang ter-loading dalam pori material. MIL-100 ter-loading azidothimidine trifosfat diuji dengan human Peripherical Blood Mononuclear Cells (PBMCs) dari darah sehat yang diinjeksi virus HIV-1-LAI. Penghambatan atau sifat anti-HIV ditunjukkan pada material MIL-100 yang mengandung azidothimidine trifosfat ini dengan persentase inhibisi mencapai $90 \%$ (Rieter et al., 2006).

\section{STUDI MOFs SEBAGAI PELAPIS/ ENKAPSULASI BEBERAPA OBAT Cu-BTC dengan 5-Fluoracil}

Penggabungan $\mathrm{Cu}$-BTC dengan 5-Fluoracil yang merupakan obat kanker payudara bertujuan untuk memperlambat pelepasan obat. Cu-BTC: 5-FU diuji aktivitas cytotoksisitasnya dengan sel kanker tipe NCI-H292 (human pulmonary mucoepidermoid carcinoma), MCF-7 (human breast adenocarcinoma), HT29 (human colorectal adenocarcinoma), dan HL60 (human promyelocytic leukimia cells). Hasil tabel 1, Cu- 
BTC: 5-FU, dan 5-Fluoracil memperlihatkan aktivitas cytotoksik melawan sel MCF-7 dan HL-60. Nilai IC $_{50}$ untuk MCF-7 menjadi sangat rendah yakni hanya $1,735 \mathrm{mg} / \mathrm{mL}$ ketika obat digabungkan dengan MOFs jika dibandingkan dengan MOFs saja atau obat saja. Hal ini berhubungan dengan pelepasan obat yang lebih lama. Hal ini mengindikasikan sifat anti kanker yang lebih baik setelah digabungkan menjadi MOFs. Penurunan yang sama terjadi juga pada sel HL-60. Nilai IC $_{50}$ menurun secara signifikan, menandakan bahwa obat yang digabungkan dengan $\mathrm{Cu}-\mathrm{BTC}$ menunjukkan sifat obat yang lebih baik.

Pelepasan obatnyapun menjadi lebih lambat yakni mencapai 48 jam dengan persentase obat terlepas sebesar $82 \%$. Sehingga obat 5-Fluoracil yang terasosiasi dengan $\mathrm{Cu}$-BTC sangat berpotensi digunakan untuk sarana pengobatan kanker yang lebih baik (Lucena et al., 2013).

Tabel 1. Nilai $\mathrm{IC}_{50}$ dibanding sel tumor lain (Lucena et al., 2013)

\begin{tabular}{cccc}
\hline Sel Uji & Cu-BTC & 5-FU & Cu-BTC/ 5-FU \\
\hline MCF-7 & 3.49 & 20 & 1.735 \\
HT-29 & $>25$ & $>25$ & $>25$ \\
HL-60 & $>25$ & 8.601 & 4.615 \\
NCI-H292 & $>25$ & $>25$ & $>25$ \\
\hline
\end{tabular}

\section{MIL-53(Fe) dan MIL-53(Cr) dengan ibuprofen}

Penelitian Horcajada et al. (2008) menggunakan dua senyawa yakni padatan MIL53(Cr) yang dikenal toksik dan senyawa yang tingkat toksiknya lebih rendah yakni MIL53(Fe) yang digabungkan dengan obat ibuprofen. Berdasarkan parameter yang diuji, penambahan temperatur maupun pengulangan impregnasi tidak mempengaruhi kapasitas loading obat. Sebaliknya, sifat dari pelarut, waktu kontak, dan rasio ibuprofen dengan padatan berpori memberikan pengaruh yang besar terhadap jumlah adsorbsi obat. Kadar ibuprofen yang teradsorp hingga akhir bergantung pada afinitas relatif antara pelarut, ibuprofen, dan material berporinya. Pelarut yang lebih sering digunakan untuk ibuprofen adalah pelarut non polar seperti heksan dibandingkan dengan etanol. Ibuprofen yang teradsorb akan lebih banyak jika perbandingan ibuprofen dengan material berpori meningkat, dan diperoleh nilai optimal 3:1. Selain itu, waktu kontak juga penting. Adsorbsi ibuprofen secara maksimum diperoleh setelah proses impregnasi selama tiga hari. Ketika ibuprofen direaksikan, gugus $\mathrm{COOH}$ dan $\mathrm{OH}$ pada framework secara kuat berinteraksi. Pada profil pelepasannya, kedua material memiliki waktu kestabilan yang berbeda. Material MIL-53(Cr) stabil pada hari ke 10, sedang MIL-53(Fe) sudah stabil pada hari ke empat. 


\section{Zn(II) dan benzena 1,3,5-tri karboksilat sebagai pengantar ibuprofen}

Telah disintesis MOFs berbasis Zn(II) dengan linker organik berupa benzena 1,3,5 trikarboksilat (BTC) (Lestari et al., 2018). Metode yang ditempuh untuk mendapatkan $\left[\mathrm{Zn}_{3}(\mathrm{BTC})\right]_{2}$ adalah melalui metode elektrokimia dan sonokimia. Kedua metode tersebut menggunakan pelarut yang sama yakni campuran etanol dan air (1:1). Sintesis secara elektrokimia dilakukan dengan tegangan 15 Volt. Sedangkan sintesis melalui metode sonokimia dengan bantuan gelombang ultrasonik berfrekuensi $40 \mathrm{kHz}$, divariasikan waktu reaksinya, 30, 60 dan 90 menit. Meskipun bahan penyusunnya sama, perbedaan metode sintesis dan waktu reaksi akan menghasilkan MOFs yang berbeda ukuran, bentuk partikel, kemampuan adsorbsi, dan profil pelepasan obat. Ukuran partikel $\left[\mathrm{Zn}_{3}(\mathrm{BTC})\right]_{2}$ yang diperoleh dari sintesis metode elektrokimia cenderung lebih besar ukuran partikelnya $(18,43 \pm 8,10 \mu \mathrm{m})$ dibandingkan $\left[\mathrm{Zn}_{3}(\mathrm{BTC})\right]_{2}$ hasil metode sonokimia yang hanya berkisar $89,3 \pm 23,29 \mathrm{~nm}$ dan $112,94 \pm 29,06 \mathrm{~nm}$. Selain itu dari morfologinya menunjukkan bentuk partikel yang berbeda. Sintesis dengan metode elektrokimia menghasilkan material yang berbentuk kristal balok dengan ukuran berskala mikro, sedangkan dari metode sonokimia, dihasilkan bentuk partikel berupa bulat (spherical), kotak, dan agglomerat dengan ukuran berskala nano untuk waktu reaksi 30, 60, dan 90 menit secara berturut-turut. Kapasitas adsorbsi material $\left[\mathrm{Zn}_{3}(\mathrm{BTC})\right]_{2}$ dari metode elektrokimia terhadap ibuprofen sebanyak $285,20 \mathrm{mg}(94.91 \%)$. Ibuprofen yang ter-loading pada $\left[\mathrm{Zn}_{3}(\mathrm{BTC})\right]_{2}$ dari metode sonokimia selama 30 menit mencapai $285,48 \mathrm{mg}$ atau $95 \%$, dan sebanyak $285,29 \mathrm{mg}$ atau $94,94 \%$ untuk material dengan lama sonikasi 60 menit. Setelah dilakukan loading ibuprofen selama tiga hari, pelepasan lambat obat ibuprofen dari MOFs, diuji secara in vitro pada kondisi PBS. Persentase profil pelepasan $85,88 \%$ ibuprofen kontrol terjadi pada 24 jam pertama. Setelah dienkapsulasi dengan $\left[\mathrm{Zn}_{3}(\mathrm{BTC})\right]_{2}$, persentase pelepasan ibuprofen pada 24 jam, hanya 25,74\% dan 25,38\% saja untuk MOFs hasil sintesis dari metode elektrokimia dan sonokimia secara berturut-turut. Penurunan nilai ini menunjukkan bahwa dengan adanya enkapsulasi obat ibuprofen dengan material pengantar obat, degradasi obat secara cepat dapat dicegah.

\section{MIL-53, MIL-101, SBA-15 dengan acetaminophen, progesteron, dan stavudin}

Pengantaran obat yang konvensional memiliki kekurangan seperti rendahnya spesifisitas terhadap jaringan yang sakit, perlunya dosis yang tinggi dan sering, serta memunculkan efek samping. Senyawa mikropori MIL-53(Fe), mesopori MIL-101, SBA15 sebagai matriks pada adsorbsi dan pengantaran obat untuk acetaminophen, 
acetaminophen, progesteron, dan stavudin telah disintesis oleh Gordon et al. (2015). Kadar loading obat $20 \mathrm{wt} \%$ telah tercapai melalui prosedur impregnasi.

Pelepasan obat secara keseluruhan senyawa stavudin dari MIL-101 membutuhkan waktu lima hari. Progesteron dilepas secara keseluruhan setelah tiga hari sedang acetaminophen setelah dua hari. Pori MIL-53(Fe) menyumbang loading obat sebesar 20\%, $16 \%$, dan $7 \%(\mathrm{~b} / \mathrm{b})$ untuk acetaminophen, stavudin, and progesteron secara berturut-turut. Beberapa obat yang secara sukses berasosiasi dengan MIL-53(Fe), terlepas secara lambat yakni enam hari untuk acetaminophen, dan lima hari untuk stavudin dan progesteron. Pelepasan obat dari MIL-101 yang cenderung lebih cepat ini dikarenakan ukuran pori yang dimiliki lebih besar dan interaksi host-guest-nya lemah. Sedangkan meskipun MIL-53(Fe) porinya cenderung kecil, tapi fleksibilitas porinya mendukung untuk penyimpanan obat. Profil pelepasan SBA-15 lebih cepat dari kedua material MOFs yang lain. Acetaminophen dan stavudin dilepas secara keseluruhan dari SBA-15 dengan waktu kurang dari satu jam. Sedang progesteron dilepas secara keseluruhan setelah empat jam.

\section{Nanopartikel magnetit termodifikasi-MOFs untuk pengantaran letrozole}

Hashemipour et al. (2017) mensintesis magnetit $\left(\mathrm{Fe}_{3} \mathrm{O}_{4}\right)$ dari prekursornya $\mathrm{FeCl}_{3} \cdot 6 \mathrm{H}_{2} \mathrm{O}$ and $\mathrm{FeCl}_{2} \cdot 4 \mathrm{H}_{2} \mathrm{O}$ yang kemudian dimodifikasi dengan hidrolisis tetraethyl orthosilicate (TEOS) sehingga diperoleh $\mathrm{Fe}_{3} \mathrm{O}_{4} @ \mathrm{SiO}_{2}$. Senyawa tersebut direaksikan kembali dengan reagen (3-Aminopropyl)triethoxysilane (APTMS) untuk menambahkan gugus amino menjadi $\mathrm{Fe}_{3} \mathrm{O}_{4} @ \mathrm{SiO}_{2}-\mathrm{NH}_{2}$. Magnetit termodifikasi ini lalu digabungkan dengan $\mathrm{Cu}\left(\mathrm{CH}_{3} \mathrm{COOH}\right) \mathrm{H}_{2} \mathrm{O}$ dan benzena asam trikarboksilat (BTC) menjadi $\left(\mathrm{Fe}_{3} \mathrm{O}_{4} @ \mathrm{SiO}_{2}-\mathrm{NH}_{2}\right) \mathrm{MOFs}$ dan diuji kemampuan dalam menyimpan dan menghantarkan obat letrozole. Letrozole adalah salah satu inhibitor aromatik yang lebih baik aktivitasnya dibandingkan tamoxifen dalam penanganan kanker payudara. Komposit memiliki ukuran partikel 20-50 nm, berbentuk bulat, sangat berpori, dan membentuk aglomerasi. Bentuknya yang bulat dan ukuran partikel yang sangat kecil (berskala nano) menyebabkan tingginya kemampuan distribusi dan meningkatkan konsentrasinya dalam pembuluh darah. Hal ini mencegah terjadinya interaksi material dengan sel endotel sehingga memperpanjang waktu hidup dari material. $\mathrm{Fe}_{3} \mathrm{O}_{4} /\left[\mathrm{Cu}_{3}(\mathrm{BTC})_{2}\right]$ yang telah disintesis, diuji kemampuan adsorbsi/enkapsulasi obatnya pada variasi pH 3 sampai 8 dan diperoleh kondisi $\mathrm{pH}$ optimum 5 dengan kandungan letrozole yang teradsorb sebanyak 8,4 mg/g. Variasi waktu hingga 60 menit pada kondisi pH 5 dalam proses adsorbsi letrozole, menunjukkan terjadinya adsorbsi $70 \%$ dari $20 \mathrm{mg} / \mathrm{L}$ letrozole yang dicapai pada menit pertama. Pelepasan obatnya diuji pada dua kondisi simulasi yakni $\mathrm{pH} \mathrm{1,2} \mathrm{yang} \mathrm{mewakili} \mathrm{kondisi}$ 
lambung dan 7,4 yang menyerupai $\mathrm{pH}$ dalam usus. Hasil penelitian menunjukkan bahwa 44\% letrozole dapat terlepas pada pH 1,2 setelah 30 menit. Adapun pada kondisi $\mathrm{pH}$ 7,4, sebanyak $80 \%$ letrozole dapat terlepas dengan waktu relatif lebih lama yakni 15 jam.

\section{MIL-100(Fe) dengan aspirin}

Metode pengapsulan obat pada material pengantar, seperti yang dijelaskan pada bab sebelumnya dapat ditempuh dengan penggabungan agen biomedis secara langsung maupun dengan penggabungan secara post synthesis. Singco et al. (2016) melakukan penelitian mengenai pengapsulan obat aspirin dengan material pengantar MIL-100(Fe). MIL-100(Fe) yang telah disintesis, dilakukan penggabungan secara post synthesis dengan aspirin. Ukuran aspirin yang relatif kecil yakni $0,41 \mathrm{~nm}$ memungkinkannya masuk pada MIL-100(Fe) yang memiliki ukuran pori 1,8 dan 2,3 nm. Kapasitas adsorpsi $\mathrm{N}_{2}$ material awal MIL-100(Fe) menurun sebesar 32\% apabila dibandingkan dengan kapasitas adsorpsi isoterm $\mathrm{N}_{2}$ MIL-100(Fe) ter-loading aspirin (ASA@MIL-100(Fe)). Penurunan ini mengindikasikan bahwa aspirin secara sukses telah masuk pada pori material pengantar. Selain itu dari analisa TOF MS, diketahui bahwa aspirin yang ter-loading setelah impregnasi mencapai $181 \%$. Uji pada kondisi PBS dengan suhu $37{ }^{\circ} \mathrm{C}$, membutuhkan waktu 14 hari untuk pelepasan obatnya.

Prosedur lain juga dilakukan dengan menggabungkan aspirin secara langsung seperti prinsip bio-MOFs. Aspirin direaksikan bersamaan ketika sintesis de novo, sehingga aspirin bertindak sebagai linker organik disamping asam trimesat pada MIL-100(Fe). Kelebihan dari teknik ini adalah tidak bergantungnya obat yang akan dikapsulasi dengan ukuran pori dari material pengantar, karena obat sudah secara langsung terikat pada rangka. Kedua material ini diuji pelepasan aspirinnya pada dua kondisi pH yakni 1,2 dan 7,4. Difusi aspirin dari material pengantar cenderung lebih lambat pada kondisi asam namun lebih cepat ketika pH-nya 7,4. Penggabungan aspirin baik secara post synthesis maupun langsung, sama-sama berpotensi sebagai material pengkapsul obat yang dapat mencegah degradasi obat ketika berinteraksi dengan sistem pencernaan yang membuat jumlah yang tertransport dalam darah berkurang (Singco et al., 2016).

\section{MOFs dengan ligan campuran sebagai pengantar ibuprofen dan doxorubicin}

MOFs $\left[\mathrm{Cu}_{3}(\mathrm{BTC})_{2}\right]$ yang disintesis dari prekursor $\mathrm{Cu}$ dengan ligan $\mathrm{H}_{3} \mathrm{BTC}$ merupakan material berpori yang dapat diaplikasikan sebagai pengantar obat 5-Fluoracil (Lucena et al., 2013). Menggunakan senyawa dasar MOFs yang sama, Sun et al. (2017) juga meneliti karakteristik Cu-BTC sebagai material pengantar obat ibuprofen (Ibu) dan doxorubicin (Dox). Kebaruan lain pada penelitian ini adalah penambahan ligan asam 
isoftalat pada sintesis $\mathrm{Cu}-\mathrm{BTC}$. Empat variasi senyawa yang disintesis diantaranya, prekursor $\mathrm{Cu}^{2+}$ dengan $100 \%$ ligan asam isoftalat (MOFs 1), 40\% BTC dan $60 \%$ asam isoftalat (MOFs 2), 70\% BTC dan 30\% asam isoftalat (MOFs 3), serta 100\% ligan BTC (MOFs 4) disintesis dengan metode hidrotermal. Impregnasi dengan obatnya dilakukan hingga 72 jam. Hasil analisis kuantitatif obat ibuprofen yang ter-loading, MOFs 4 menunjukkan jumlah ibuprofen paling rendah dibandingkan variasi lainnya. Berbeda dengan obat doxorubicin, hasil loading terendah ada pada MOFs 1. Kapasitas ibuprofen dan doxorubicin paling tinggi, tercapai ketika komposisi BTC:asam isoftalatnya 2:3 atau pada MOFs 2. Hasil pengukuran pori menunjukkan ukuran pori untuk MOFs 1 mencapai 14,67 nm, sedang MOFs 2 2,12 nm, MOFs 3 2,09, dan MOFs 4 2,28 nm. Relatif besarnya ukuran pori MOFs 1 maupun MOFs 4 merupakan salah satu faktor rendahnya kapasitas loading obat meskipun waktu kontaknya 72 jam. Obat akan tersimpan dalam pori material, jika ukuran pori dengan ukuran obatnya cocok. Selain itu interaksi antara gugus karboksil dengan ibuprofen menjadi faktor lain, mampunya obat dapat terenkapsulasi dalam material pengantar. Uji pelepasan Dox dilakukan pada beberapa kondisi pH yakni 3,8; 5,8; dan 7,4 dalam PBS bersuhu $37{ }^{\circ} \mathrm{C}$. Profil pelepasan yang optimum dicapai ketika kondisi asam (pH 3,8), sedangkan pada dua kondisi pH lain, hanya dapat melepas obat Dox $<30 \%$ meski sudah 80 jam. Uji pelepasan ibuprofen pada pH 7,4 untuk MOFs 1 dan 2 mampu melepas ibuprofen 100\%, sedang MOFs 3 dan 4 berturut-turut 90\% dan 70\%. Hasil uji cytotoksisitas keempat MOFs terhadap sel HEK 293A menunjukkan persentase sel hidup (cell viability) lebih dari $82 \%$, sehingga keempat senyawa pengantar yang digunakan sifat toksisitasnya rendah.

\section{Zn-BDC pengantar obat doxorubicin}

Doxorubicin adalah salah satu obat yang digunakan di bidang medis onkologi sebagai untuk pembunuh sel tumor. Agen antineoplastik ini adalah obat kemoterapi kelas antrasiklin yang diproduksi dari bakteri Streptomyces peutius. Kajian mengenai obat ini, ditemukan terjadinya penurunan kadar secara cepat pada level plasma,sehingga pelapisan doxorubicin diperlukan untuk mencegah degradasi obat ini. Sejalan dengan Sun et al. (2017), Vasconcelos et al. (2017) juga menguji senyawa MOFs untuk pengantaran obat doxorubicin, hanya saja MOFs yang disintesis adalah $\left[\mathrm{Zn}(\mathrm{BDC})\left(\mathrm{H}_{2} \mathrm{O}\right)_{2}\right] \mathrm{n}$ atau $\mathrm{Zn}-\mathrm{BDC}$.

Hasil simulasi komputasi untuk Zn-BDC menunjukkan adanya ikatan hidrogen juga interaksi $\pi-\pi$ stacking yang terjadi antara cincin aromatik pada susunan lapisannya yang zig zag. Interaksi $\pi-\pi$ inilah yang menjanjikan interaksi yang kuat jika digabungkan 
dengan obat doxorubicin yang juga memiliki cincin aromatis. Sehingga obat ini dapat bergabung pada permukaan maupun tersisip diantara dua lapis lamelar Zn-BDC.

Analisis hasil pengapsulan doxorubicin menunjukkan, bahwa pada setiap 0,1 g ZnBDC terkandung 0,017 g doxorubicin. Pelepasan doxorubicin dari Zn-BDC sebesar 51,4\% dicapai selama 48 jam. Profilnya cenderung baik karena tidak mengalami efek ledakan (burst effect) atau pelepasan obat dengan sangat cepat. Uji in vitro sitotoksisitas DOXO@ZnBDC terhadap HT29, MCF-7, dan NCI-H-292 menunjukkan nilai 72,6\%, 47,4\%, dan 77\%. Nilai tersebut mengindikasikan aktivitas inhibisi. Apabila 1-20\% maka aktivitasnya nol, 20-50\% berarti aktivitas rendah, aktivitas moderat jika 50-70\%, dan aktivitas signifikan jika 70-100\%, sehingga DOXO@ZnBDC memiliki aktivitas inhibisi yang signifikan dalam mencegah pertumbuhan sel HT29 dan NCI-H-292.

\section{Komposit magnetik $\mathrm{Fe}_{3} \mathrm{O}_{4} / \mathrm{Cu}-\mathrm{BTC} / \mathrm{GO}$ sebagai pengantar obat ibuprofen}

Li et al. (2017) melakukan sintesis $\mathrm{Fe}_{3} \mathrm{O}_{4} / \mathrm{Cu}-\mathrm{BTC} / \mathrm{GO}$ secara satu tahap dengan metode solvotermal. Komposit ini dikaji kemampuan adsorbsi obat ibuprofen dan profil pelepasannya diperbandingkan dengan $\mathrm{Fe}_{3} \mathrm{O}_{4}$ saja dan $\mathrm{Fe}_{3} \mathrm{O}_{4} / \mathrm{Cu}-\mathrm{BTC}$. Proses adsorbsi ibuprofen dilakukan selama 72 jam pada suhu ruang dengan pelarut sikloheksana. Setelah pengeringan pada suhu $70{ }^{\circ} \mathrm{C}$, dijalankan uji pelepasan ibuprofen pada kondisi PBS. Kapasitas loading ibuprofen oleh material $\mathrm{Fe}_{3} \mathrm{O}_{4}$ tergolong kurang memuaskan yakni sekitar $10 \mathrm{mg} / \mathrm{g}$. Namun, terjadi peningkatan yang sangat signifikan setelah ditambahkan $\mathrm{Cu}-\mathrm{BTC}$ menjadi $\mathrm{Fe}_{3} \mathrm{O}_{4} / \mathrm{Cu}-\mathrm{BTC}$, yakni hingga $70 \mathrm{mg} / \mathrm{g}$. Ibuprofen yang tersimpan lebih banyak lagi dicapai ketika material tersebut dikompositkan dengan GO (graphene oksida), nilainya lebih dari $90 \mathrm{mg} / \mathrm{g}$. Tingginya persentase loading obat ini, dikarenakan keberadaan pori pada $\mathrm{Cu}-\mathrm{BTC}$, mode satu lapis dari GO, luasnya area, dan adanya gugus karbonil dan hidroksil yang dapat mengadakan interaksi ikatan hidrogen sehingga ibuprofen tidak hanya berada pada pori tapi juga dapat mengadakan interaksi dengan material pengantar obat.

Profil pelepasan ibuprofen pada $\mathrm{Fe}_{3} \mathrm{O}_{4}$ terjadi sangat cepat, sedangkan untuk komposit $\mathrm{Fe}_{3} \mathrm{O}_{4} / \mathrm{Cu}-\mathrm{BTC}$ dan $\mathrm{Fe}_{3} \mathrm{O}_{4} / \mathrm{Cu}-\mathrm{BTC} / \mathrm{GO}$ memiliki profil pelepasan yang lebih baik. Pelepasan ibuprofen mendekati $100 \%$ terjadi secara sangat cepat pada 12 jam pertama untuk material magnetik. Sebanyak 93\% ibuprofen terlepas dari $\mathrm{Fe}_{3} \mathrm{O}_{4} / \mathrm{Cu}-\mathrm{BTC}$ memerlukan waktu 60 jam, dan pada jam yang sama, jumlah ibuprofen yang terlepas dari komposit $\mathrm{Fe}_{3} \mathrm{O}_{4} / \mathrm{Cu}-\mathrm{BTC} / \mathrm{GO}$ adalah $81 \%$. Adapun pada jam ke 12, pelepasan ibuprofen dari $\mathrm{Fe}_{3} \mathrm{O}_{4} / \mathrm{Cu}-\mathrm{BTC}$ dan $\mathrm{Fe}_{3} \mathrm{O}_{4} / \mathrm{Cu}-\mathrm{BTC} / \mathrm{GO}$ secara berturut-turut yakni $60 \%$ dan $40 \%$. Hasil pengujian ini menunjukkan bahwa penambahan MOFs $\mathrm{Cu}-\mathrm{BTC}$ maupun $\mathrm{Cu}-\mathrm{BTC} /$ 
GO, melalui keberadaan pori dan interaksi hidrogen yang dapat terjadi, mampu meningkatkan jumlah ibuprofen yang terserap dan memperlambat proses pelepasan ibuprofen tersebut (Li et al., 2017).

\section{KESIMPULAN}

Pengembangan MOFs sebagai pengantar dan pelepas lambat obat telah banyak dilakukan, sampai saat ini. Variasi yang umum menitikberatkan pada pengkombinasian berbagai macam organik linker dan ion logam untuk menyesuaikan ukuran pori, stabilitas, maupun interaksi yang diinginkan. Peneliti-peneliti juga telah melakukan kajian pengapsulan obat-obat tertentu dengan variasi material MOFs-nya, dan menunjukkan kemampuan adsorbsi, waktu pelepasan obat, interaksi antara MOFs dengan obat, serta stabilitas yang berbeda. Prinsip sintesis material MOFs sebagai pengantar dan pelepas lambat obat harus bebas dari unsur toksik sehingga tidak membahayakan tubuh, bersifat biocompatible dan biodegradable sehingga setelah melepas obat, material pembawa dapat terurai dengan sendirinya dengan tidak membahayakan tubuh. Selain itu, sistem yang terus dikembangkan yakni material dibuat berskala nano agar dapat masuk ke dalam jaringan sel tubuh yang sakit secara lebih mudah maupun dengan cara mengkompositkan dengan beberapa material berpori lain seperti grafit oksida maupun silika dan senyawa paramagnetik seperti $\mathrm{Fe}_{3} \mathrm{O}_{4}$ untuk meningkatkan luas permukaan dan stabilitas untuk adsorpsi biomolekul dan dapat dengan mudah dikumpulkan dengan medan magnet luar.

\section{DAFTAR PUSTAKA}

Abid, H.R., Tian, H., Ang, H.M., Tade, M.O., Buckley, C.E. and Wang, S., 2012. Nanosize Zr-Metal Organic Frameworks (UiO-66) for Hydrogen and Carbon Dioxide storage. Chemical Engineering Journal 187, 415-420.

Allendorf, M.D., Bauer, C.A., Bhakta, R.K. and Houk, R.J.T., 2009. Critical Review: Luminescent Metal Organic Frameworks. Chemical Society Reviews 38, 13301352.

Bangham, A.D. and Horne, R.W., 1964. Negative Staining of Phospholipids and Their Structural Modification by Surface-active Agents as Observed in the Electron Microscope. Journal of Molecular Biology 8, 660-668.

Bernini, M.C., Jimenez, D.F., Pasinetti, M., Pastor, A.J.R. and Snurr, R.Q., 2014. Screening of Bio-Compatible Metal-Organic Frameworks as Potential Drug Carriers using Monte Carlo Simulations. Journal of Materials Chemistry B 2, 766774 
Cho, H.Y., Yang, D.A., Kim, J., Jeong, S.Y., and Ahn, W.S., 2012. $\mathrm{CO}_{2}$ Adsorption and Catalytic Application of Co-MOF-74 Synthesized by Microwave Heating. Catalysis Today 185, 35-40.

Eddaoudi, M., Kim, J. Rosi, N., Vodak, D., Wachter, J., O’Keeffe, M., and Yaghi, O.M. 2002. Systematic Design of Pore Size and Functionality in Isoreticular MOFs and Their Application in Methane Storage. Science 295, 469-472.

Fromm, K.M., 2008. Coordination Polymer Network with S-Block Metal Ions. Coordination Chemistry Reviews 252, 856-885.

Gordon, J., Kazemian, H., and Rohani, S., 2015. MIL-53(Fe), MIL-101, and SBA-15 Porous Materials: Potential Platforms for Drug Delivery. Materials Science and Engineering C 47, 172-179.

Goyer, R.A., 1996. Toxic Effects of Metals, In Casarett \& Doull's Toxicology, The Basic Science of Poisons. Klaassen, C.D., McGraw Hill Health Professions Division, ISBN 0071054766.

Hashemipour, S. and Panahi, H.A., 2017. Fabrication of Magnetite Nanoparticles Modified with Copper Based Metal Organic Framework for Drug Delivery System of Letrozole. Journal of Molecular Liquids, doi: 10.1016/j.molliq.2017.07.127.

He, Q. and Shi. J., 2011. Mesoporous Silica Nanoparticle based Nano Drug Delivery Systems: Synthesis, Controlled Drug Release and Delivery, Pharmacokinetics and Biocompatibility. Journal of Materials Chemistry 21, 5845-5855.

Hinks, N.J., McKinlay, A.C., Xiao, B., Wheatley, P.S., and Morris, R.E., 2010. Metal Organic Frameworks as NO Delivery Materials for Biological Applications. Microporous and Mesoporous Materials 129, 330 - 334.

Horcajada, P., Alvarez, C.M., Ramila, A., Pariente, J.P., and Regí, M.V., 2006. Controlled Release of Ibuprofen from Dealuminated Faujasites. Solid State Science 8 (12), 1459-1465.

Horcajada, P., Chalati, T., Serre, C., Gillet, B., Sebrie, C., Baati, T., Eubank, J.F., Heurtaux, D., Clayette P., Kreuz, C., Chang, J., Hwang, Y.K., Marsaud, V., Bories, P.N., and Cynober, L., 2010. Porous Metal-Organic Frameworks Nanoscale Carriers as Potential Platform for Drug Delivery and Imaging. Nat. Mat 9, 172-178.

Horcajada, P., Serre, C., Regí, M.V., Sebban, M., Taulelle, F. and Férey, G., 2006. Metal Organic Frameworks as Efficient Materials for Drug Delivery. Angewandte Chemie International Edition 45 (36), 5974-5978.

Horcajada, P., Serre, C., Regí, M.V., Sebban, M., Taulelle, F., and Férey, G., 2008. Porous Metal-Organic Frameworks for a Controlled Drug Delivery. Journal of the American Chemical Society 130, 6774-6780.

Joaristi, A.M., Juan-AlcanPiz, J., Serra-Crespo, P., Kapteijn, F., and Gascon. J., 2012. Electrochemical Synthesis of some Archetypical $\mathrm{Zn}^{2+} \mathrm{Cu}^{2+}$ and $\mathrm{Al}^{3+}$ Metal Organic Frameworks. Crystal Growth 12, 3489-3498. 
Kathryn, M., Taylor, L., Jin, A., and Lin, W., 2008. Angewandte Chemie International Edition 47, $7722-7725$.

Ke, F., Yuan, Y.P., Qiu, L.G., Shen, Y.H., Xie, A.J., Zhu, J.F., Tianc, X.Y., and Zhang, L.D., 2011. Facile Fabrication of Magetic Metal-Organic Frameworks Nanocomposites for Potential Targeted Drug Delivery. Journal of Materials Chemistry 21, 3843-3848.

Lee, J.Y., Farha, O.K., Roberts, J., Scheidt, K.A., Nguyen, S.T, and Hupp, J.T., 2009. Review: Metal Organic Frameworks as Catalysts. Chemical Society Reviews 38, $1450-1459$.

Lestari, W.W., Arvinawati, M., Martien, R., and Kusumaningsih, T., 2018. Green and Facile Synthesis of MOF and Nano MOF Containing Zinc(II) and Benzen 1,3,5-Tri Carboxylate and Its Study in Ibuprofen Slow-Release. Materials Chemistry and Physics 204, 141-146.

Li, H., Eddaoudi, M., O'Keeffe, M. and Yaghi, O.M., 1999. Design and Synthesis of an Exceptionally Stable and Highly Porous Metal Organic Frameworks. Nature 402, 276-279.

Li, L., Liu, Y., Sun, K., He, Y., Liu, L., 2017. One Step Synthesis of Magnetic Composite $\mathrm{Fe}_{3} \mathrm{O}_{4} / \mathrm{Cu}-\mathrm{BTC} / \mathrm{GO}$. Materials Letters 197, 196-200

Li, L., Wu, Y.Q., Sun, K.K., Zhang, R., Fan, L., Liang, K.K., and Mao, L.B., 2016. Controllable Preparation and Drug Loading Properties of Core-Shell Microspheres $\mathrm{Fe}_{3} \mathrm{O}_{4} @ \mathrm{MOFs} / \mathrm{GO}$. Materials Letters 162, 207-210

Liu, B., He, Y., Han, L., Singh, V., Xu, X., Guo, T., Meng, F., Xu, X., York, P., Liu, Z., and Zhang, J., 2017. Microwave-Assisted Rapid Synthesis of $\gamma$-Cyclodextrin Metal-Organic Frameworks for Size Control and Efficient Drug Loading. Crystal Growth Design 17, 1654-1660

Lucena, F.R.Q.S, Larissa, C.C., Rodrigues, M.D., Silva, T.G., Pereira, V.R.A., Militão, G.C.G., Fontes D.A.F., Pedro, J.R.N., Silva, F.F., and Nascimento, S.C., 2013. Induction of Cancer Cell Death by Apoptosis and Slow Release of 5-fluoracil from Metal-Organic Frameworks Cu-BTC. Biomedicine \& Pharmacotherapy 67, 707713.

Ma, L.Q., Falkowski, J.M., Abney, C., and Lin, W.B., 2010. A Series of Isoreticular Chiral Metal-Organic Frameworks as a Tunable Platform for Asymmetric Catalysis. Nat. Chem. 2, 838-846.

Ma, L., Jin, A., Xie, Z., and Lin, W., 2009. Freeze Drying Significantly Increases Permanent Porosity and Hydrogen Uptake in 4,4-Connected Metal Organic Frameworks. Angewandte Chemie International Edition 48, 9905-9908.

Miller, S.R., Heurtaux, D., Baati, T., Horcajada, P., Grene`che, J.M., and Serre., 2010. Biodegradable Therapeutic MOFs for The Delivery of Bioactive Molecules. $C$. Chemical Communication 46, 4526-4528. 
Mueller, U., Schubert, M., Teich, F., Puetter, H. Schierledantt, K., and Pastre, J., 2006. Application: Metal Organic Frameworks Prospective Industrial Applications. Journal of Materials Chemistry 16, 626-636.

Qiu, L.G., Li, Z.Q., Wu, Y., Wang, W., Xu, T., and Jiang, Xia, 2008, Facile Synthesis of Nanocrystals of a Microporous Metal-Organic Framework by an Ultrasonic Method and Selective Sensing of Organoamines. Chemical Communications, 3642-3644

Riehemann, K., Schneider, S.W., Luger, T.A., Godin, B., Ferrari, M., and Fuchs, H. 2009. Review: Nanomedicine-Challenge and Perspective. Angewandte Chemie International Edition 48, 872-897.

Rieter, W.J., Pott, K.M., Taylor, K.M.L., and Lin, W., 2008. Nanoscale Coordination Polymers for Platinum-Based Anticancer Drug Delivery. Journal of the American Chemical Society 130, 11584-11585.

Rieter, W.J., Taylor, K.M.L., An, H., Lin, W., and Lin, W., 2006. Nanoscale MetalOrganic Frameworks as Potential Multimodal Contrast Enhancing Agents. Journal of the American Chemical Society 128, 9024-9025.

Rocca, J.D., Liu, D., and Lin, W., 2011. NMOFs for Biomedical Imaging dan Drug Delivery. Accounts of Chemical Research 44 (10), 957-968.

Rosi, N.L., Eckert, J., and Eddaodi, M., 2003. Hydrogen Storage in Microporous Metal Organic Frameworks. Science 300 , 1127-1129.

Seo, Y.K., Hundal, G., Jang, I.T., Hwang, Y.K., Jun, C.H. and Chang, J.S., 2009. Microwave Synthesis of Hybrid Anorganic-Organic Materials Including Porous $\mathrm{Cu}_{3}(\mathrm{BTC})_{2}$ from $\mathrm{Cu}(\mathrm{III})-$ Trimesat Mixture. Microporous Mesoporous Materials 119 (1), 331-337.

Shi, J., Votruba, A.R., Farokhzad, O.C., and Langer, R., 2010. Nanotechnology in Drug Delivery and Tissue Engineering: From Discovery to Applications. Nano Letter 10, 3223-3230.

Sindoro, M., Yanai, N., Jee, A., and Granick, S., 2014. Colloidal-Sized Metal-Organic Frameworks: Synthesis and Application. Accounts of Chemical Research 47 (2), 459-469.

Singco, B., Liu, L.H., Chen, Y.T., Shih, Y.H., Huang, H.Y., and Lin, C.H., 2015. Approaches to Drug Delivery: Confinement of Aspirin In MIL-100(Fe) and Aspirin in The De Novo Synthesis of Metal-Organic Frameworks. Microporous and Mesoporous Materials, doi: 10.1016/j.micromeso.2015.08.017.

Sun, C.Y., Qin, C., Wang, X.L., and Su, Z.M., 2013. Review: Metal Organic Frameworks as Potential Drug Delivery Systems. Expert Opinion on Drug Delivery 10 (1), 89101.

Sun, K., Li, L., Yu, X.L., Liu, L., Meng, Q., Wang, F., and Zhang, R., 2017. Functionalization of Mixed Ligand Metal Organic Frameworks as The Transport Vehicles for Drugs. Journal of Colloid and Interface Science 486, 128-135 
Taylor, K.M.L., Della, R.J., Xie, Z., Tran, S., and Lin, W., 2009. Postsynthetic Modifications of Iron-Carboxylate Nanoscale Metal Organic Frameworks for Imaging and Drug Delivery. Journal of the American Chemical Society 131, 14261 -14263 .

Taylor, K.M.L., Rieter, W.J., and Lin, W., 2008. Manganese-based Nanoscale MetalOrganic Frameworks for Magnetic Resonance Imaging. Journal of the American Chemical Society 130, 14358-14359.

Taylor, K.M.L., Rocca, J.D., Huxford, R.C., Lin, W., 2010. Feature Article: Hybrid Nanomaterials for Biomedical Applications. Chemical Communication 46, 58325849 .

Tranchemontagne, D.J., Cortes, J.L.M., O'Keeffe, M., and Yaghi, O.M., 2009. Review: Secondary Building Units, Nets and Bonding in the Chemistry of Metal-Organic Frameworks. Chemical Society Reviews 38 1257-1283.

Vasconcelos, I.B., Wanderley, K.A., Rodrigues, N.M., da Costa Jr., N.B., Freire, R.O., Junior, S.A., 2016. Host-guest Interaction of ZnBDC-MOF + Doxorubicin: A Theoretical and Experimental Study. Journal of Molecular Structure, doi: 10.1016/j.molstruc.2016.11.034

Vimont, A., Goupil, J.M., Lavelley, J.C., Daturi, M., Surble, S., Serre, C., Millange, F., Ferrey, G., and Audebrand, N., 2006. Investigation of Acid Sites in Zeotypic Giant Pores Chromium(III) Carboxylate. Journal of the American Chemical Society 128, 3218-3227.

Xie, Z.Y., Huang, X., Wang, Z., Niu, L., Teng, M., and Li, J., 2007. Rational Design of MOFs Constructed from Modified Aromatic Amino Acids. Chemistry A European Journal 13, 9399 - 9405.

Yang, D.A., Cho, H.Y., Kim, J., Yang, S.T. and Ahn, W.S., 2012. $\mathrm{CO}_{2}$ Capture and Conversion Using Mg-MOF-74 Prepared by a Sonochemical Method. Energy Environmental Science 5, 6465-6473. 